ERGONOMICS, 1986, VOL. 29, NO. 11, 1455-1467

\title{
Air transport pilot involvement in general aviation accidents
}

\author{
By Santo Salvatore, Mary D. Stearns, M. Stephen Huntley, Jr. \\ and PETER MENGERT \\ Department of Transportation, Transportation Systems Center, \\ Cambridge, Massachusetts 02142, U.S.A.
}

\begin{abstract}
General aviation (GA) fatal accident records of airport transport pilots (ATPs) were compared to those of private pilots (PVTs). ATPs are safer GA pilots than the PVTs. They have comparable exposure in GA airplanes and account for $7.5 \%$ of all certified to fly, but only $3.5 \%$ of the fatal accidents. ATPs are less often involved in pilot-induced accidents. Nearly $50 \%$ of ATP pilot-induced accidents occur during aerobatics. Often these risky aerial operations are performed below a safe altitude and are associated with the descriptors 'careless' and 'reckless'. The ATP aerobaticsrelated fatality is likely to occur in a multi-wing aeroplane with which he has little experience. The ATP aerobatics-related accident is likely to be of the spin, stall, or controlled flight into terrain variety, and to occur in summer or early autumn.
\end{abstract}

\section{Introduction}

The present study was conducted to provide a basis for developing accident countermeasures focused on pilot characteristics and accident type. In the past, it was common to assume that pilot skill and experience were inversely related to accident rates. It has been commonly stated by fixed-base operators and safety specialists that to become a safer pilot it is necessary to fly more. Certainly it is true that, in a given set of flying circumstances, the aviator with the most experience should be the one most capable of flying safely. However, both anecdotal and accident data are available to show that with experience comes the pilot's willingness to encounter more challenging flight regimes and, perhaps consequently, to accept increased risk. Research by the Federal Aviation Administration's (FAA) Safety Analysis Division (1982) revealed that the accident rate of 20-25-year-old private pilots was over $20 \%$ higher for pilots with 101-400 hours of flight time than it was for those with 51-100 hours of ftight time. FAA records also indicate that high-time pilots are more apt to fly a variety of aircraft. Accident statistics indicate that low time (less than 50 hours) is directly related to accident probability.

The present study was conducted to further explore the relationship between pilot characteristics and accident type, and to describe the kinds of accidents that involve advanced aviators. This was done by examining and comparing relative involvement of professional air transport pilots (ATPs) and private pilots (PVTs) in general aviation accidents incurred during personal, non-commercial flights.

It was hypothesized that ATPs would have lower accident rates, but would also have proportionately higher rates in accident categories which reflect flight regimes more typical of advanced aviators.

The study used data from the FAA's accident incident data system (AIDS) to investigate the characteristics of accidents experienced by both ATPs and PVTs. In addition, the National Transportation Safety Board's (NTSB) accident narratives were reviewed to describe characteristics of typical fatally injured pilot holding an ATP certificate. 


\subsection{Study population}

The study used data from 13680 general aviation (GA) accidents occurring between 1973 and 1983, inclusive. This represents approximately $30 \%$ of the 45627 accidents that occurred during that period in GA aircraft.

The accidents selected for study met the following criteria:

(1) The GA flight was flown for personal (non-commercial) reasons.

(2) The aircraft involved was a powered fixed-wing aeroplane.

(3) The accident was a single-aircraft accident.

(4) The aeroplane had not more than two pilots on board.

(5) The pilot in command held an ATP or PVT certificate.

(6) The ATP-certificated pilots were employed as professional pilots.

Figure 1 summarizes 45627 GA accidents occurring between 1973 and 1983 inclusive. The accident incidence data was selected using the study criteria specified in the left-hand column of figure 1 . The boxes report accident frequencies for each of the categories at each level of the analysis. The total population of 13680 pilots consisted of 461 ATPs and 13219 PVTs.

The criteria for selecting from amongst $45627 \mathrm{GA}$ accidents were based on the following rationale: Mid-air collisions were excluded because of the difficulty in apportioning blame; this reduced the selection to 44585 accidents. The study was restricted to $\mathrm{GA}$ accidents involving only aeroplanes, to ensure similarity of aircraft flight characteristics and flight regimes, reducing the total to 39408 accidents. The number of flight crew on board was limited to one or two, further reducing the accident set to 27295 . Restricting the study to personal fying excludes 16542 accidents which occurred during commercial flights for agriculture, business, instruction, air taxis or other purposes; the number of accidents is thus reduced to 20 753. The field was further restricted to accidents involving ATPs or private pilots, yielding 613 and 13219 accidents, respectively. Limiting accidents to those ATP-certificated pilots who are professional pilots reduces the ATP accidents to 461 . The subset of accidents studied therefore totals 13680 , combining professional ATPs and private pilots.

\subsection{Pilot-fatal accidents}

Figure 2 provides the same information for pilot-fatal accidents. For each category, the number of pilot-fatal accidents/fatalities is provided. This study covers 96 ATP professionals and 2358 private pilots who were involved in 2454 fatal accidents. A subset of 76 ATP professionals is drawn from the 96 fatalities to be used to describe characteristics of the ATP fatalities.

\section{ATP pilot-fatal accidents: absolute and relative numbers}

In absolute numbers, for a 2-year period, ATPs were about as likely to be killed in GA accidents flown for personal reasons as they were flying professionally for the air carriers. A total of ten ATPs were killed in personal GA accidents during 1982 to 1983, and ten ATPs were also killed in air carrier accidents in the same 2-year period.

Table 1 shows that for the AIDS sample used in this study, the proportion of fatal GA accidents to all GA accidents was slightly higher for ATPs than for PVTs. This small difference is not statistically reliable.

Table 2 provides a percentage comparison of the flying population with the accident-involved population. 


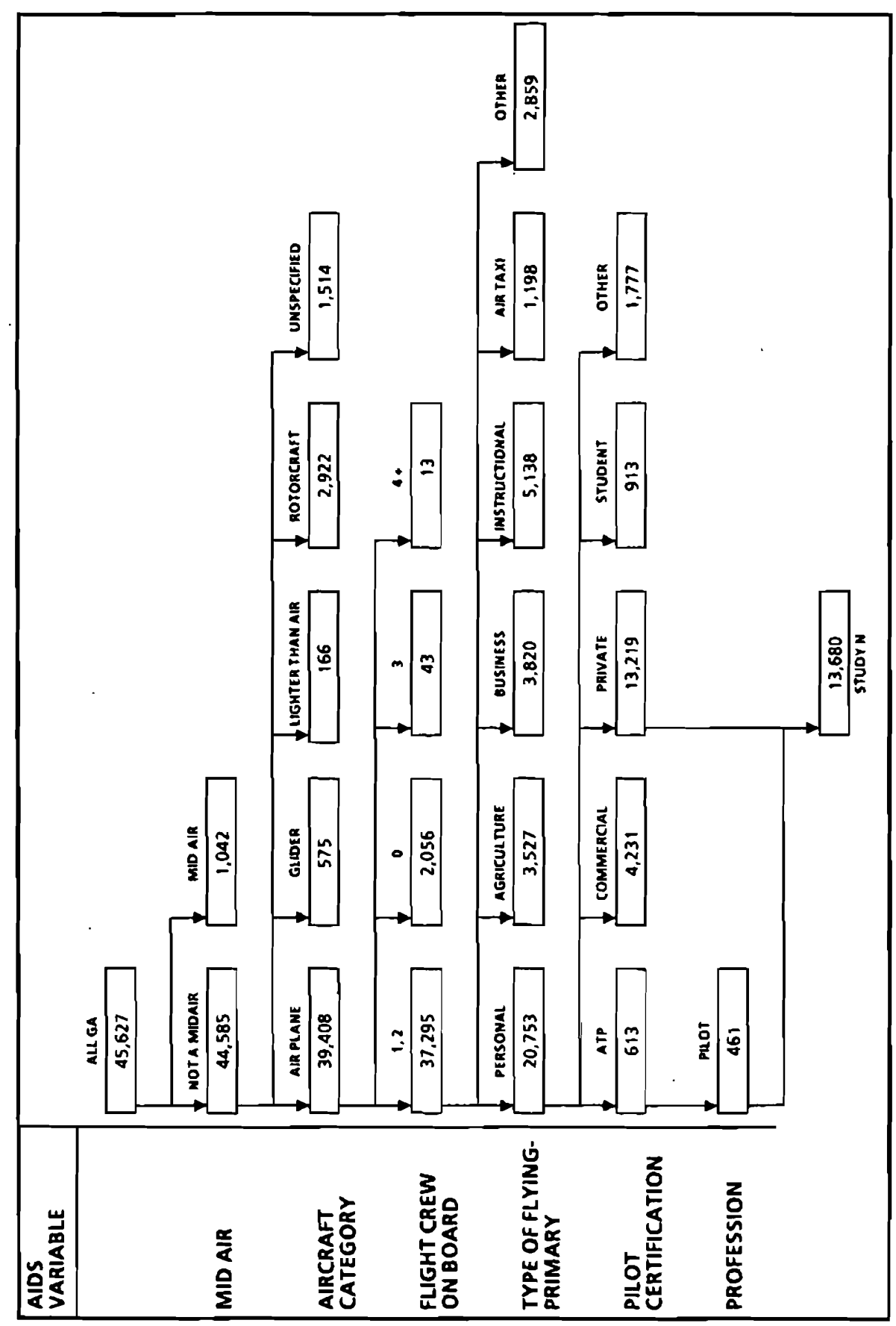

总 


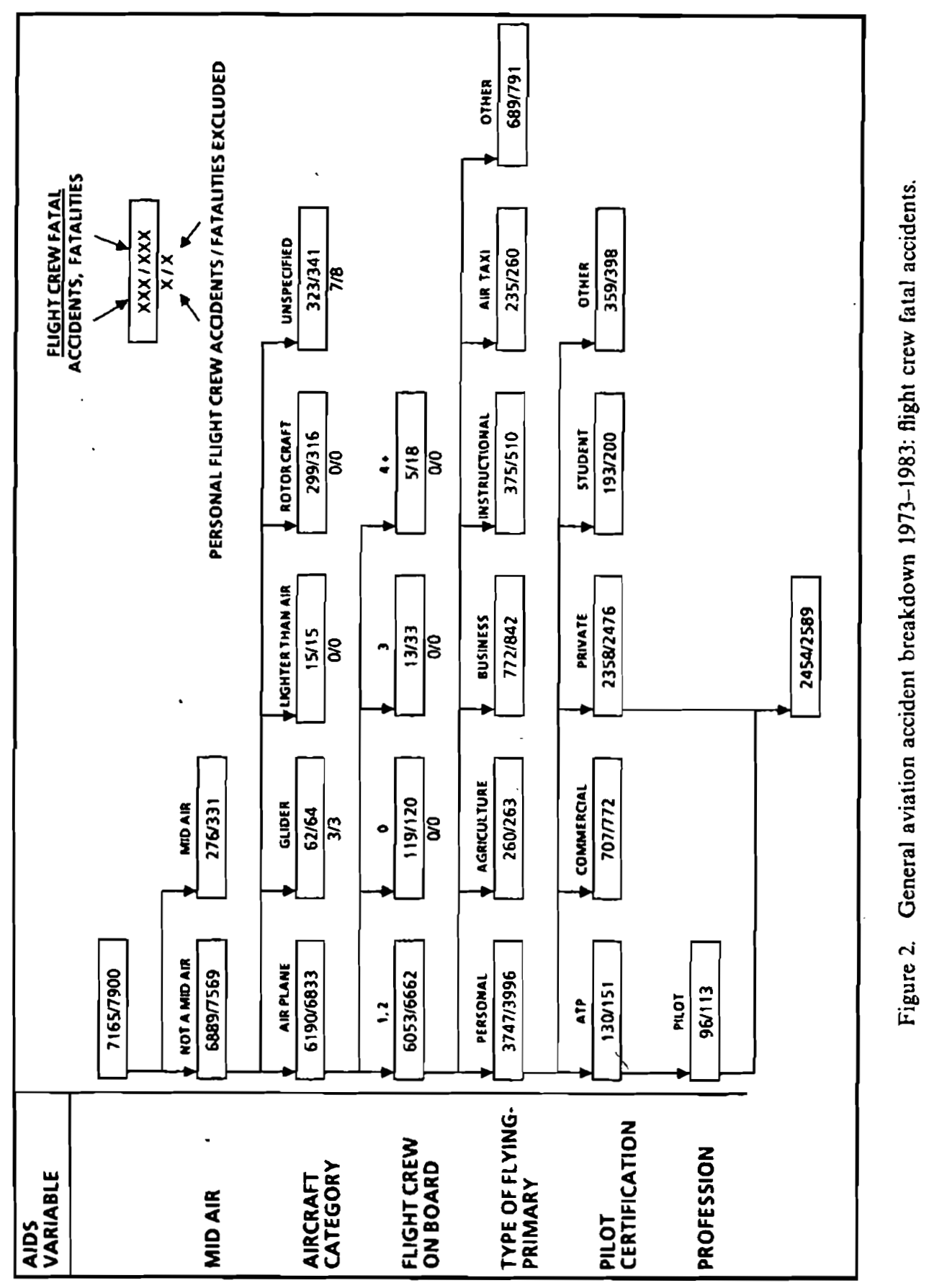


Table 1. Proportion of accidents which were fatal for the two types of pilots.

\begin{tabular}{crrr}
\hline Certificate & Fatal & Total & $\begin{array}{l}\text { Percentage } \\
\text { Fatal/total }\end{array}$ \\
\hline ATP & 96 & 461 & 20.8 \\
PVT & 2358 & 13219 & 17.9 \\
\hline
\end{tabular}

Table 2. Proportion of pilot types involved in accidents.

\begin{tabular}{cccc}
\hline & $\begin{array}{c}\text { Average percentage } \\
\text { per year } \\
\text { of total pilot } \\
\text { population } \\
\text { during 1973-83 }\end{array}$ & $\begin{array}{c}\text { Percentage } \\
\text { involved } \\
\text { in fatal } \\
\text { accidents }\end{array}$ & $\begin{array}{c}\text { Petcentage } \\
\text { involved in } \\
\text { non-fatàls }\end{array}$ \\
\hline ATP & 7.5 & 3.5 & 2.8 \\
PVT & 42.5 & 62.9 & 63.9 \\
\hline
\end{tabular}

Table 3. Hours flying time by pilot certification and accident involvement.

\begin{tabular}{|c|c|c|c|c|c|}
\hline & \multirow{3}{*}{ 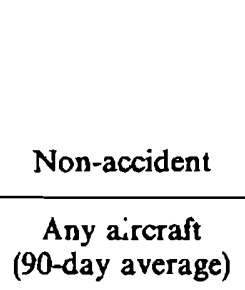 } & \multicolumn{4}{|c|}{ Accident involved sample } \\
\hline & & \multicolumn{2}{|c|}{$\begin{array}{c}\text { Any } \\
\text { aircraft } \\
\text { (last } 90 \text { days) }\end{array}$} & \multicolumn{2}{|c|}{$\begin{array}{c}\text { The accidental aircraf } \\
\text { make/model } \\
\text { (last } 90 \text { days) }\end{array}$} \\
\hline & & $\begin{array}{c}\text { All } \\
\text { accidents }\end{array}$ & $\begin{array}{c}\text { Fatal } \\
\text { accidents }\end{array}$ & $\begin{array}{c}\text { All } \\
\text { accidents }\end{array}$ & $\begin{array}{c}\text { Fatal } \\
\text { accidents }\end{array}$ \\
\hline ATP & 187 & 127 & 122 & 25 & 32 \\
\hline PVT & 40 & 29 & 27 & 21 & 20 \\
\hline Ratio: ATP/PVT & $4 \cdot 7$ & $4 \cdot 4$ & $4 \cdot 5$ & $1 \cdot 2$ & 1.6 \\
\hline
\end{tabular}

Though ATPs made up an average of $7.5 \%$ of the flying population (Carter 1983) over the 11 -year span, they accounted for only $3.5 \%$ and $2.8 \%$ of the fatal and non-fatal accidents, respectively. The ATPs, therefore, were under-represented in terms of the flying population in both GA fatal and non-fatal, non-commercial flying accidents.

\subsection{Index of exposure: Hours of flying time}

The number of pilots in each certification category is, at best, a very rough index of exposure. Flying time is a better index of exposure to risk. Table 3 provides a comparison of mean hours of flying time for accident involved and non-accident involved ATPs and PVTs, in terms of their total flying time and their flying time in GAtype aircraft. For the non-accident data, $3440 \mathrm{GA}$ pilots were interviewed upon arrival at 93 randomly selected airports regarding their hours flown in 1980 (Hairston et al. 1983). The accident sample is from AIDS.

The interview data showed that ATPs flew about 4.7 times longer hours than PVTs in 1980. (The ATPs fiy commercially as well as for personal reasons). Approximately the same flight time ratio, 4.4 to 4.5 , is found for those pilots involved in accidents as 
those not involved. The similarities in flight time patterns obtained from non-accident interviews with those obtained from the accident data base support the use of the accident flight time information as an index of exposure.

In the plane in which their accident occurred, ATPs have at least the same amount of, and probably more, flying exposure as the PVTs. Taken together, tables 2 and 3 indicate that ATPs as a group have fewer accidents than PVTs in proportion to both their numbers and their hours of exposure to risk, indicating that ATPs are safer GA pilots than PVTs.

\section{Accident characteristics and causes}

The accident characteristics, causes, and pilot behaviours which differentiate the two pilot groups are described below. Four variables are used to compare and contrast ATPs and PVTs for both all accidents and fatal accidents. These variables are discussed in the next four sections.

\subsection{General cause category}

The general cause category variable is the broadest accident classification in AIDS. It assigns each accident to one of nine categorics representing the causes of GA accidents, these categories being themselves necessarily broad in scope.

Table 4 demonstrates that five of the nine categories differentiate statistically between the two types of pilots within the parameter of all accidents. The chi-square test was used to determine if the observed frequency in any category was significantly different $(p<0.05)$ from the expected frequency (Spence et al. 1968).

Table 4. General cause category: number, percentage of total, $\chi^{2}$ of all categories.

\begin{tabular}{|c|c|c|c|c|c|c|c|c|}
\hline \multirow[b]{2}{*}{ General cause categories } & & \multicolumn{3}{|c|}{ All accidents } & & \multicolumn{3}{|c|}{ Fatal accidents } \\
\hline & & ATP & PVT & $x^{2}$ & & ATP & PVT & $\chi^{2}$ \\
\hline Design & $\begin{array}{l}N \\
\%\end{array}$ & $\begin{array}{r}3 \\
0.7\end{array}$ & $0.2^{22}$ & - & $\begin{array}{l}\mathrm{N} \\
\%\end{array}$ & $\begin{array}{l}0 \\
0\end{array}$ & $0.1^{3}$ & - \\
\hline Maniufacturer & $\begin{array}{l}N \\
\%\end{array}$ & $\begin{array}{r}2 \\
0.4\end{array}$ & $0.1^{15}$ & - & $\begin{array}{l}\mathrm{N} \\
\%\end{array}$ & $\begin{array}{r}1 \\
1 \cdot 1\end{array}$ & $0-1^{2}$ & - \\
\hline $\begin{array}{l}\text { Improper } \\
\text { maintenance }\end{array}$ & $\begin{array}{l}\mathbf{N} \\
\%\end{array}$ & $\begin{array}{l}16 \\
3 \cdot 5\end{array}$ & $\begin{array}{l}133 \\
1 \cdot 0\end{array}$ & $25 \cdot 0^{* *}$ & $\begin{array}{l}\mathrm{N} \\
\%\end{array}$ & $\begin{array}{r}2 \\
2 \cdot 1\end{array}$ & $0.4^{9}$ & - \\
\hline $\begin{array}{l}\text { Inadequate } \\
\text { maintenance }\end{array}$ & $\begin{array}{l}\mathrm{N} \\
\%\end{array}$ & $\begin{array}{r}7 \\
1.5\end{array}$ & $\begin{array}{c}141 \\
1 \cdot 1\end{array}$ & 0.8 & $\begin{array}{l}N \\
\%\end{array}$ & $\begin{array}{r}1 \\
1 \cdot 1\end{array}$ & $0.3^{6}$ & - \\
\hline $\begin{array}{l}\text { Pilot and } \\
\text { maintenance }\end{array}$ & $\begin{array}{l}\mathrm{N} \\
\%\end{array}$ & $\begin{array}{r}27 \\
5.9\end{array}$ & $\begin{array}{l}420 \\
3 \cdot 2\end{array}$ & $9.9^{*}$ & $\begin{array}{l}\mathbf{N} \\
\%\end{array}$ & $\begin{array}{r}4 \\
4 \cdot 2\end{array}$ & $\begin{array}{c}65 \\
2 \cdot 8\end{array}$ & - \\
\hline Miscellaneous & $\begin{array}{l}\mathbf{N} \\
\%\end{array}$ & $\begin{array}{r}24 \\
5 \cdot 2\end{array}$ & $\begin{array}{c}469 \\
3.6\end{array}$ & 3.4 & $\begin{array}{l}\mathrm{N} \\
\%\end{array}$ & $\begin{array}{r}1 \\
1 \cdot 1\end{array}$ & $\begin{array}{l}30 \\
1 \cdot 3\end{array}$ & - \\
\hline Undetermined & $\begin{array}{l}\mathbf{N} \\
\%\end{array}$ & $\begin{array}{r}42 \\
9 \cdot 1\end{array}$ & $\begin{array}{l}631 \\
4 \cdot 8\end{array}$ & $17 \cdot 2^{* *}$ & $\begin{array}{l}\mathrm{N} \\
\%\end{array}$ & $\begin{array}{r}17 \\
17 \cdot 7\end{array}$ & $\begin{array}{l}220 \\
9 \cdot 3\end{array}$ & $6.9 *$ \\
\hline $\begin{array}{l}\text { Operation deficiency } \\
\text { other than pilot }\end{array}$ & $\begin{array}{l}\mathbf{N} \\
\%\end{array}$ & $\begin{array}{r}33 \\
7 \cdot 2\end{array}$ & $\begin{array}{l}415 \\
3 \cdot 2\end{array}$ & $22 \cdot 0^{* *}$ & $\begin{array}{l}\mathrm{N} \\
\%\end{array}$ & $\begin{array}{l}0 \\
0\end{array}$ & $\begin{array}{c}21 \\
0.9\end{array}$ & - \\
\hline Pilot & $\begin{array}{l}\mathbf{N} \\
\%\end{array}$ & $\begin{array}{r}306 \\
66 \cdot 5\end{array}$ & $\begin{array}{l}10961 \\
83.0\end{array}$ & $14 \cdot 6^{* *}$ & $\begin{array}{l}\mathbf{N} \\
\%\end{array}$ & $\begin{array}{r}69 \\
72 \cdot 6\end{array}$ & $\begin{array}{l}1999 \\
84.9\end{array}$ & 1.6 \\
\hline
\end{tabular}

$\chi^{2}$, test of statistical significance; *, significant at 0.01 level; **, significant at 0.001 level; insufficient expected $N$ for computation. 
The ATPs have a significantly greater proportion of all accidents than the PVTs in the following categories: improper maintenance, inadequate maintenance, pilot and maintenance, operational deficiency other than pilot, and undetermined. Only in the general cause category where the pilot is the main accident-producing factor ave the ATPs proportionally less involved in all accidents than the PVTs. This suggests that a higher percentage of ATP accidents are the result of factors not involving pilot skill.

A similar distribution of general cause categories holds for fatal accidents, but the differences in distribution of accident causes between the two pilot groups are not statistically significant.

The major conclusion is that ATPs are less likely to have pilot-induced accidents of all types. It appears that ATPs are also less likely to have pilot-induced fatal accidents, but the trend is not statistically significant.

\subsection{Phase of fight}

In the following analyses, only accidents which may be considered due to pilot error, i.e. the accidents in the pilot-induced subcategory, are analysed. This subpopulation contains 69 ATP and 1999 PVT fatalities.

Phase of flight is categorized into 55 separate operations by AIDS. The large number of categories increases precision in referring to the phase of flight, but makes statistical comparisons difficult by reducing the number of cases in the cross-tabulation cells. This is particularly true for pilot-fatal cells. In order to increase the number of cases in each cell, it is necessary to combine closely-related categories.

Table 5 shows that, on the whole, ATPs and PVTs are not differentiated on approach, landing, and take-off accidents. However, in proportion to their numbers,

Table 5. Phase of flight, pilot-induced accidents only: Number, percentage of total, $\chi^{2}$.

\begin{tabular}{|c|c|c|c|c|c|c|c|c|}
\hline \multirow[b]{2}{*}{ Phase of flight } & \multicolumn{4}{|c|}{ All accidents } & \multicolumn{4}{|c|}{ Fatal accidents } \\
\hline & & ATP & PVT & $\chi^{2}$ & & ATP & PVT & $x^{2}$ \\
\hline $\begin{array}{l}\text { Approach, landing, } \\
\text { take-off }\end{array}$ & $\begin{array}{l}\mathrm{N} \\
\%\end{array}$ & $\begin{array}{c}181 \\
59 \cdot 2\end{array}$ & $\begin{array}{l}7012 \\
64 \cdot 0\end{array}$ & 1.1 & $\begin{array}{l}\mathbf{N} \\
\%\end{array}$ & $\begin{array}{c}18 \\
26 \cdot 1\end{array}$ & $\begin{array}{l}561 \\
28 \cdot 1\end{array}$ & 0.12 \\
\hline $\begin{array}{l}\text { IFR approach, } \\
\text { landing, takeoff }\end{array}$ & $\begin{array}{l}\mathbf{N} \\
\%\end{array}$ & $\begin{array}{r}9 \\
2 \cdot 9\end{array}$ & $\begin{array}{l}129 \\
1 \cdot 2\end{array}$ & $7 \cdot 3^{* *}$ & $\begin{array}{l}\mathrm{N} \\
\%\end{array}$ & $\begin{array}{c}6 \\
8.7\end{array}$ & $\begin{array}{l}74 \\
3.7\end{array}$ & $4 \cdot 2^{*}$ \\
\hline $\begin{array}{l}\text { Other approach } \\
\text { landing, takeoff }\end{array}$ & $\begin{array}{l}\mathrm{N} \\
\%\end{array}$ & $\begin{array}{l}172 \\
56 \cdot 2\end{array}$ & $\begin{array}{l}6883 \\
62.9\end{array}$ & 2.9 & $\begin{array}{l}\mathrm{N} \\
\%\end{array}$ & $\begin{array}{c}12 \\
17 \cdot 4\end{array}$ & $\begin{array}{l}487 \\
24 \cdot 4\end{array}$ & $1 \cdot 4$ \\
\hline Cruise & $\begin{array}{l}\mathrm{N} \\
\%\end{array}$ & $\begin{array}{r}43 \\
14 \cdot 1\end{array}$ & $\begin{array}{l}1898 \\
17 \cdot 3\end{array}$ & 1.9 & $\begin{array}{l}\mathbf{N} \\
\%\end{array}$ & $\begin{array}{c}11 \\
15 \cdot 9\end{array}$ & $\begin{array}{l}752 \\
37.6\end{array}$ & $8 \cdot 6^{* *}$ \\
\hline Aerobatics & $\begin{array}{l}\mathrm{N} \\
\%\end{array}$ & $\begin{array}{r}42 \\
13 \cdot 7\end{array}$ & $\begin{array}{l}708 \\
6 \cdot 5\end{array}$ & $23 \cdot 5^{* * * *}$ & $\begin{array}{l}\mathbf{N} \\
\%\end{array}$ & $\begin{array}{c}34 \\
49 \cdot 3\end{array}$ & $\begin{array}{l}406 \\
20-3\end{array}$ & $26 \cdot 2^{* * *}$ \\
\hline Forced landing & $\begin{array}{l}\mathrm{N} \\
\%\end{array}$ & $\begin{array}{r}21 \\
6.9\end{array}$ & $\begin{array}{l}590 \\
5 \cdot 4\end{array}$ & $1 \cdot 2$ & $\begin{array}{l}\mathrm{N} \\
\%\end{array}$ & $\begin{array}{c}3 \\
4 \cdot 3\end{array}$ & $\begin{array}{l}47 \\
2 \cdot 4\end{array}$ & 1.0 \\
\hline Unknown & $\begin{array}{l}\mathbf{N} \\
\%\end{array}$ & $\begin{array}{r}4 \\
1 \cdot 3\end{array}$ & $\begin{array}{l}232 \\
2 \cdot 1\end{array}$ & 0.9 & $\begin{array}{l}\mathbf{N} \\
\%\end{array}$ & $\begin{array}{c}3 \\
4 \cdot 3\end{array}$ & $\begin{array}{l}223 \\
11 \cdot 2\end{array}$ & 2.8 \\
\hline $\begin{array}{l}\text { Ground, practice, } \\
\text { other }\end{array}$ & $\begin{array}{l}\mathrm{N} \\
\%\end{array}$ & $\begin{array}{r}15 \\
4.9\end{array}$ & $\begin{array}{l}511 \\
4.7\end{array}$ & 0.1 & $\begin{array}{l}\mathbf{N} \\
\%\end{array}$ & $\begin{array}{l}0 \\
0\end{array}$ & $\begin{array}{r}10 \\
0\end{array}$ & - \\
\hline
\end{tabular}

$\chi^{2}$, test of statistical significance; *, significant at $0-05$ level; ${ }^{* *}$, significant at $0-01$ level; ***, significant at 0.001 level; - , insufficient expected $N$ for computation. 
ATPs are significantly more involved in approach, landing and take-off accidents and fatalities during instrument flight rules (IFR). This may simply reflect greater flying activity of the ATPs under instrument meteorological conditions.

PVTs are involved more often than ATPs in fatal accidents during normal cruise. $38 \%$ of PVT fatalities occur during this phase compared with $16 \%$ for the ATPs.

The most striking fact in table 5 is the disproportionate involvement of ATPs in accidents during aerobatics. Of all pilot-induced accidents, $13.7 \%$ of the ATPs' occur in this phase compared to $6.5 \%$ of the PVTs'. Of the fatal accidents, nearly $50 \%$ of the ATPs are killed in pilot-induced accidents during aerobatics. The corresponding figure for the PVTs is $20 \cdot 3 \%$.

\subsection{Cause factor $A$}

The exact cause of the accident is classified by AIDS into one of over 100 possible cause factors. To simplify analysis, categories with less than five total accidents have been deleted and the remainder consolidated into eight broader categories.

In table 6 it is seen that the ATPs are less often involved in all accidents in the traffic pattern. This may be attributed to their superior flying skills. A similar situation is found in accidents in which weather is a prominent factor. The PVTs have three times the weather-related accidents of the ATPs. More significantly, in over one third of all PVT pilot-fatal accidents, weather plays a very important role. Weather-related fatal accidents occur five times more frequently for the PVTs than the ATPs.

Expanding on the previous finding that a disproportionate number of ATP accidents occur during aerobatic manoeuvres, we find that the ATPs, much more often than the PVTs, perform accident-causing aerobatics in formation below a safe altitude.

Table 6. Cause factor A, pilot induced only: Number, percentage of total, $\chi^{2}$ in selected subcategories.

\begin{tabular}{|c|c|c|c|c|c|c|c|c|}
\hline \multirow[b]{2}{*}{ Cause factor $\mathrm{A}$} & & \multicolumn{3}{|c|}{ All accidents } & \multicolumn{4}{|c|}{ Fatal accidents } \\
\hline & & ATP & PVT & $x^{2}$ & & ATP & PVT & $\chi^{2}$ \\
\hline Flight planning & $\begin{array}{l}\mathrm{N} \\
\%\end{array}$ & $\begin{array}{c}32 \\
10 \cdot 5\end{array}$ & $\begin{array}{l}836 \\
7.7\end{array}$ & $3 \cdot 2$ & $\begin{array}{l}N \\
\%\end{array}$ & $\begin{array}{c}3 \\
4 \cdot 5\end{array}$ & $\begin{array}{r}69 \\
3.5\end{array}$ & 0.1 \\
\hline $\begin{array}{l}\text { Traffic pattern } \\
\text { errors }\end{array}$ & $\begin{array}{l}\mathbf{N} \\
\%\end{array}$ & $\begin{array}{c}44 \\
14 \cdot 5\end{array}$ & $\begin{array}{l}2781 \\
25 \cdot 4\end{array}$ & $14 \cdot 3^{*}$ & $\begin{array}{l}\mathrm{N} \\
\%\end{array}$ & $\begin{array}{c}4 \\
5 \cdot 9\end{array}$ & $\begin{array}{c}72 \\
3.8\end{array}$ & $0-9$ \\
\hline Weather & $\begin{array}{l}\mathrm{N} \\
\%\end{array}$ & $\begin{array}{c}8 \\
2 \cdot 7\end{array}$ & $\begin{array}{l}927 \\
8.4\end{array}$ & $12 \cdot 3^{*}$ & $\begin{array}{l}\mathrm{N} \\
\%\end{array}$ & $\begin{array}{c}5 \\
7 \cdot 4\end{array}$ & $\begin{array}{l}691 \\
34.7\end{array}$ & $14 \cdot 8^{*}$ \\
\hline Collision & $\begin{array}{l}\mathrm{N} \\
\%\end{array}$ & $\begin{array}{l}30 \\
9.9\end{array}$ & $\begin{array}{l}960 \\
8.8\end{array}$ & $0-3$ & $\begin{array}{l}\mathrm{N} \\
\%\end{array}$ & $\begin{array}{c}14 \\
20-3\end{array}$ & $\begin{array}{l}353 \\
17.8\end{array}$ & 0.2 \\
\hline $\begin{array}{l}\text { Fuel system } \\
\text { errors }\end{array}$ & $\begin{array}{l}\mathrm{N} \\
\%\end{array}$ & $\begin{array}{c}3 \\
1.8\end{array}$ & $\begin{array}{l}599 \\
5 \cdot 5\end{array}$ & 0.8 & $\begin{array}{l}\mathrm{N} \\
\%\end{array}$ & $\begin{array}{l}0 \\
0\end{array}$ & $\begin{array}{r}45 \\
2 \cdot 3\end{array}$ & - \\
\hline $\begin{array}{l}\text { Aerobatics low } \\
\text { formation }\end{array}$ & $\begin{array}{l}\mathrm{N} \\
\%\end{array}$ & $\begin{array}{l}17 \\
5 \cdot 6\end{array}$ & $\begin{array}{l}91 \\
0.8\end{array}$ & $70 \cdot 5^{*}$ & $\begin{array}{l}N \\
\%\end{array}$ & $\begin{array}{c}15 \\
21 \cdot 7\end{array}$ & $\begin{array}{r}73 \\
3.7\end{array}$ & $52 \cdot 2^{*}$ \\
\hline Other cruise & $\begin{array}{l}\mathrm{N} \\
\%\end{array}$ & $\begin{array}{c}47 \\
15 \cdot 4\end{array}$ & $\begin{array}{l}1568 \\
14 \cdot 4\end{array}$ & 0.2 & $\begin{array}{l}\mathrm{N} \\
\%\end{array}$ & $\begin{array}{c}19 \\
27 \cdot 7\end{array}$ & $\begin{array}{l}524 \\
26 \cdot 4\end{array}$ & 0.01 \\
\hline Ground operations & $\begin{array}{l}\mathrm{N} \\
\%\end{array}$ & $\begin{array}{c}52 \\
16.9\end{array}$ & $\begin{array}{l}1572 \\
14.5\end{array}$ & 1.5 & $\begin{array}{l}\mathbf{N} \\
\%\end{array}$ & - & - & - \\
\hline
\end{tabular}

$\chi^{2}$, test of statistical significance; *, significant at $0-001$ level; -, insufficient expected $N$ for computation. 


\subsection{Supplementary factor $A$}

Supplementary factor A provides additional information on the accident. This factor indicates potentially causal activity prominent in the accident.

Table 7 confirms the previous finding that weather plays a more important part in PVT than ATP accidents. It also indicates that, although ATPs make mistakes that involve them in accidents as often as PVTs, they are less often involved in accidents due to lack of skills.

ATPs are involved more often than PVTs in accidents associated with risk and overconfidence. Of all pilot-induced fatal accidents, a full $58 \%$ fall into this category. This result parallels Booze's (1977) finding that total flight time or experience is related to accident incidence in a complex fashion. He suggests that greater total flight time can be associated with overconfidence.

\section{Characteristics of ATP pilot fatalities}

Table 8 contrasts the ATP pilot fatalities associated with aerobatics with ATP pilot fatalities due to other causes. This comparison of ATP pilot fatalities is drawn from the 76 cases where there was only one ATP on board.

\subsection{Type of accident}

Overall, the ATP pilot-fatal accidents tended to be on land regardless of phase of flight. Approximately four-fifths of all ATP fatalities had impact locations on land; aerobatics-related fatalities did not differ in their impact location from fatalities in other phases of flight.

Table 7. Supplementary factor A, pilot induced accidents: Number, percentage of total, $\chi^{2}$.

\begin{tabular}{|c|c|c|c|c|c|c|c|c|}
\hline \multirow[b]{2}{*}{ Supplementary factor $A$} & \multicolumn{4}{|c|}{ All accidents } & & \multicolumn{3}{|c|}{ Pilot fatal } \\
\hline & & ATP & PVT & $\chi^{2}$ & & ATP & PVT & $\chi^{2}$ \\
\hline $\begin{array}{l}\text { Weather } \\
\text { WX, } \\
\text { WX-brief received, } \\
\text { WX-brief not received, } \\
\text { WX-not briefed }\end{array}$ & $\begin{array}{l}\mathbf{N} \\
\%\end{array}$ & $\begin{array}{l}13 \\
4 \cdot 2\end{array}$ & $\begin{array}{l}882 \\
8 \cdot 1\end{array}$ & $5 \cdot 4^{*}$ & $\begin{array}{l}\mathrm{N} \\
\%\end{array}$ & $\begin{array}{c}9 \\
13 \cdot 0\end{array}$ & $\begin{array}{l}615 \\
30 \cdot 8\end{array}$ & $6 \cdot 7^{* *}$ \\
\hline Mistake & $\begin{array}{l}\mathbf{N} \\
\%\end{array}$ & $\begin{array}{c}74 \\
24 \cdot 2\end{array}$ & $\begin{array}{l}3080 \\
28 \cdot 1\end{array}$ & 1.6 & $\begin{array}{l}\mathrm{N} \\
\%\end{array}$ & $\begin{array}{l}6 \\
8 \cdot 7\end{array}$ & $\begin{array}{l}228 \\
11 \cdot 4\end{array}$ & $0-4$ \\
\hline $\begin{array}{l}\text { Unskilled in } \\
\text { operation or aircraft }\end{array}$ & $\begin{array}{l}\mathbf{N} \\
\%\end{array}$ & $\begin{array}{l}28 \\
9 \cdot 1\end{array}$ & $\begin{array}{l}1533 \\
14 \cdot 2\end{array}$ & $5 \cdot 3^{*}$ & $\begin{array}{l}\mathbf{N} \\
\%\end{array}$ & $\begin{array}{l}2 \\
2 \cdot 9\end{array}$ & $\begin{array}{l}215 \\
10-8\end{array}$ & 3.8 \\
\hline $\begin{array}{l}\text { Risk: Overconfidence } \\
\text { Calculated risk, } \\
\text { careless, reckless, } \\
\text { misjudgment }\end{array}$ & $\begin{array}{l}\mathrm{N} \\
\%\end{array}$ & $\begin{array}{l}148 \\
48 \cdot 4\end{array}$ & $\begin{array}{l}4210 \\
38 \cdot 4\end{array}$ & $\begin{array}{l}7 \cdot 8^{* * *} \\
\end{array}$ & $\begin{array}{l}\mathbf{N} \\
\%\end{array}$ & $\begin{array}{l}40 \\
58 \cdot 0\end{array}$ & $\begin{array}{l}585 \\
29 \cdot 3\end{array}$ & $19 \cdot 2^{* * *}$ \\
\hline $\begin{array}{l}\text { Other operational } \\
\text { factors }\end{array}$ & $\begin{array}{l}N \\
\%\end{array}$ & $\begin{array}{l}29 \\
9 \cdot 5\end{array}$ & $\begin{array}{l}859 \\
7.8\end{array}$ & 0.9 & $\begin{array}{l}N \\
\%\end{array}$ & $\begin{array}{c}8 \\
11 \cdot 6\end{array}$ & $\begin{array}{l}298 \\
14 \cdot 9\end{array}$ & - \\
\hline Technical factors & $\begin{array}{l}\mathbf{N} \\
\%\end{array}$ & $\begin{array}{l}13 \\
4 \cdot 2\end{array}$ & $\begin{array}{c}362 \\
3 \cdot 3\end{array}$ & 1.0 & $\begin{array}{l}\mathrm{N} \\
\%\end{array}$ & $\begin{array}{l}3 \\
4 \cdot 3\end{array}$ & $\begin{array}{l}55 \\
2 \cdot 8\end{array}$ & 0.5 \\
\hline
\end{tabular}

$\chi^{2}$, test of statistical significance; *. significant at 0.05 level; ${ }^{* *}$, significant at 0.01 level; ***, significant at 0.001 level; - insufficient expected $N$ for computation. 
Table 8. ATP fatalities by type of accident and phase of flight (Source: NTSB Brief Format Reports).

\begin{tabular}{lcc}
\hline Type of accident* & $\begin{array}{c}\text { ATPs in acrobatic } \\
\text { phase of flight }\end{array}$ & $\begin{array}{c}\text { ATPs in other } \\
\text { phases of flight }\end{array}$ \\
\hline $\begin{array}{l}\text { Stall } \\
\text { Stall: spin }\end{array}$ & $4(15 \%)$ & $3(6 \%)$ \\
$\begin{array}{l}\text { Collided with trees } \\
\text { Collided with ground or water, } \\
\text { controlled }\end{array}$ & $6(23 \%)$ & $4(7 \%)$ \\
$\begin{array}{l}\text { Collided with ground or water, } \\
\text { uncontrolled }\end{array}$ & $1(4 \%)$ & $7(13 \%)$ \\
$\begin{array}{l}\text { Turbulence } \\
\text { Engine failure (malfunction) }\end{array}$ & $8(30 \%)$ & $4(7 \%)$ \\
Air frame failure in flight & $0(0 \%)$ & $14(26 \%)$ \\
Fire explosion in flight & $0(0 \%)$ & $1(2 \%)$ \\
Collided with object: animais, wires, & $00 \%)$ & $7(13 \%)$ \\
poles, ditching, hard landing, propeller, & $3(12 \%)$ & $2(4 \%)$ \\
rotor failure, undetermined & $0(0 \%)$ & $1(2 \%)$ \\
Total† & & \\
\hline
\end{tabular}

* For accidents, multiple answers provided for type of accident. All categories mentioned are included in the table.

† Only covers accidents in 1973-1981 inclusive; type of accident classification omitted in 1982 and 1983 data.

There are differences in the types of planes flown by ATPs who had fatal accidents. One quarter of the aeroplanes involved in aerobatics-related accidents were multi-wing planes, while those involved in accidents related to other causes were all single-wing planes.

Examination of aeroplanes by make and model was done to show the types of planes most often involved in ATPs' fatal GA accidents. In aerobatics-related accidents, four types of aeroplanes are involved in $31 \%$ of these fatal accidents; they are the Bellanca 7KCAB, Cessna 182, Pitts 2-1 and Pitts Speical S-1. By contrast, eight aeroplane types account for $37 \%$ of the fatal ATP accidents occurring in other phases of flight; they are the Aeronca C3, Beech 35, Bellanca 7KCAB, Cessna 117RG, Cessna 402, Mitsubishi MUZB35, Piper PA23 and Piper PA30.

Of the 76 fatalities reviewed, 33 occurred during aerobatics. These fatalities were generally of a different type from non-aerobatic fatalities. Table 8 shows that ATPs in aerobatic accidents tend to have stall-related or controlled collisions with ground or water. In contrast, the other ATP pilot-fatalities were involved in more uncontrolled collisions with ground or water, engine failure or malfunction and collisions with trees.

\subsection{ATP characteristics}

ATPs' accidents are not usually associated with excessive rates of alcohol, or with drug or medicine abuse. Evidence from general aviation suggest alcohol-impairment is a factor in 16\% of accidents (Ryan and Mohler 1980). A study of GA fatal accidents reported pilots with excessive blood alcohol levels in $9 \%$ of the accidents studied (Lacefield et al. 1975). In comparison, alcohol is a factor in $8 \%$ of the accidents analysed in this paper. 
Table 9. Total hours in type of aeroplane involved in fatal accident, ATP fatalities (source: NTBS Brief Format Reports).

\begin{tabular}{lccc}
\hline & $\begin{array}{c}\text { ATPs in acrobatic } \\
\text { phase of flight }\end{array}$ & $\begin{array}{c}\text { ATPs in other } \\
\text { phases of flight }\end{array}$ & $\begin{array}{c}\text { Total } \\
\text { ATPs }\end{array}$ \\
Total hours in type of aeroplane involved in fatal accident* & & 566 & 450 \\
Mean hours & 245 & 196 & 153 \\
Median hours & 115 & 819 & 730 \\
\hline Standard deviation & 727 &
\end{tabular}

* $\chi^{2}$ tests were performed to determine if the mean total flying hours in type was significantly different. Results are the following. "ATPs in acrobatic phase of flight" vs. "ATPs in other phases of flight" $=$ significant, $p>0-01$.

Table 9 shows that total ATP flying time in the type of aircraft flown at the time of the fatal accident averages 450 hours. ATPs killed in the aerobatic flight phase had less than one half the length of time in the type, with $\mathbf{2 4 5}$ hours, as compared with pilots killed during other phases of flight, with 566 hours. In $5 \%$ of all ATP fatalities, records specifically state that the ATP was unfamiliar with or new to the type of plane flown.

Fatally injured ATP pilots have come from all parts of the United States, but the distribution is uneven: about $41 \%$ lived in the Southern and Southwestern regions.

Pilot fatalities tend to occur in the states of residence. Approximately $13 \%$ of the ATPs killed lived in California and $13 \%$ of the fatal accidents had an impact location in California. Other states with higher frequencies of both fatally injured ATPs' residences and impact locations are Texas, Arizona, Florida and Georgia.

Overall, April is the month with the highest incidence of ATP-involved fatal recreational GA accidents from all causes. Aerobatic-related accidents peak during the good-weather months in summer and early autumn, from June to October. In contrast, November and February are the peak months for other ATP fatal accidents. This may show the influence of weather effects on such accidents due to the intensified wind and air mass patterns at the beginning and end of winter.

\section{Summary and conclusions}

In this study, the accident records of PVTs and ATPs flying for personal reasons in GA aircraft were compared. These records included 13219 non-fatal and 2454 fatal accidents for PVTs, and 461 nonfatal and 96 fatal accidents for ATPs who were professional pilots.

Our results show that ATPs are under-represented in both GA fatal and non-fatal accidents. ATPs comprise $7.5 \%$ of all certified to fly, but they account for only approximately $3 \%$ of the GA accidents.

The exposure in GA aircraft flown for personal reasons is comparable to or greater than that of PVTs. Because they are under-represented in GA accidents, it is concluded that the ATP is a safer GA pilot than the PVT.

ATPs are involved less often that PVTs in GA pilot-induced accidents of all types, indicating that a higher percentage of ATP accidents are the result of factors not directly related to flying skills.

The most striking finding is that ATP accidents more often involve aerobatics. Of the ATP pilot-induced fatal accidents, nearly $50 \%$ occur during aerobatics. Often these 
risky aerial operations are performed below safe altitudes and are associated with such descriptors as 'careless' and 'reckless'.

Lack of experience with a particular type of plane may be an important factor in ATP fatalities. The pilots in 5\% of the ATP fatalities were new to the type of plane in which they were killed. ATPs fatally injured during acrobatics tended to have less experience in the aircraft type than ATPs killed during other phases of flight.

ATPs involved in aerobatics-related fatalities differ from ATP fatalities in other flight phases in several ways. One quarter of the aerobatics-related ATP fatalities occurred in multi-wing airplanes, unlike all of the ATP fatalities in other phases. Aerobatics-related ATP fatalities were more likely to involve spin, stall or controlled flight into terrain or water than ATP fatalities in other phases of flight. There was a seasonal difference in the occurrence of aerobatics-related ATP fatalities. Aerobaticsrelated ATP accidents peaked in summer and autumn; all other ATP-fatal accidents peaked in late autumn and winter. This difference many reflect the fact that most aerobatics and open-cockpit flying is done during the summer and early autumn.

Les statistiques d'accidents mortels dans l'aviation (GA) se rapportant aux pilotes des transports aériens (ATP) ont été comparées à celles se rapportant aux pilotes privés (PVT). Les pilotes ATP sont, en ce qui concerne les accidents, des pilotes plus sûrs que les PVT. Ils ont des expositions comparables dans les avions de la GA et représentent 7,5\% de tous les licenciés de vol, mais seulement $3,5 \%$ des accidents mortels. Les ATP sont moins souvent impliqués dans les accidents imputables au pilote. Près de 50\% de ce type d'accident chez les ATP se produisent au cours des aérobaties. Souvent ces opérations aériennes à risque élevé sont effectuées trop près du sol et sont associées aux descripteurs de négligence et de témérité. Chez les ATP l'accident à la suite d'une aérobatie se produit le plus souvent avec un avion multi-aile qu'ils ne connaissent pas suffisamment; il est le plus souvent du type descente en vrille, perte de vitesse ou vol contrôlé sur terrain varié et se produit plus souvent en été ou en début d'automne.

Berichte der allgemeinen Luftfahrt (GA) über tödliche Unfalle von Luftverkehrspiloten (ATPs) wurden mit denen von Privatpiloten (PVT) verglichen. ATPs sind sicherere GA Piloten als die PVTs. Sie haben eine vergleichbare Exposition in GA Flugzeugen und besitzen $7,5 \%$ aller Fluglizenzen, weisen aber nur 3,5\% tödliche Unfalle auf. ATPs sind weniger oft in Unfalle verwickelt, die durch den Piloten hervorgerufen werden. Ungefähr 50\% der durch ATP Piloten hervorgerufenen Unfälle ereignen sich während Kunstfügen. Oft werden diese gefährlichen fliegerischen Operationen unterhalb sicherer Höhe ausgeführt und werden mit den Deskriptoren Sorglosigkeit und Nachlässigkeit in Verbindung gebracht. Das Vorkommen tödlicher Unfâlle der ATPs bei Kunstfügen ist am wahrscheinlichsten beim Fliegen mit einem 'multi-wing'Flugzeug, mit dem der Pilot wenig Erfahrung hat. Die Ursachen für die tōdlichen Unfâlle der ATPs während den Kunstflügen sind Trudeln, Durchsacken des Flugzeuges oder Flüge unter Verkehrskontrolle in unterschiedlichster Art von Gelände und sie ereignen sich im Sommer oder im frühen Herbst.

\section{References}

BoozB, C. F., 1977, Epidemiologic investigation of occupation, age, and exposure in general aviation. Aviation, Space, and Environmental Medicine, 48, 1080-1091.

Carter, P. W., 1983, U.S. Civil Airmen Statistics (Washington, D.C.: Federal Aviation ADMINISTRATION).

Hairston, J., Wright, M. R., Narva, A., and SChWENCK, J., 1983, General Aviation pilot and aircraft activity survey. Report No. DOT-TSC-FAA-83-2, Federal Aviation Administration, Washington, D.C.

LACefield, A. J., RoBerTs, P. A., and BLossom, C. W., 1975, Toxicological findings in fatal civil aviation accidents, fiscal years 1968-1974. Aviation, Space, and Environmental Medicine, 46, $1030-1032$. 
Natronal Transportation Safety Board, 1984, Annual Review of Aircraft Accident Data 1981 (U.S. General AVIATION).

Ryan, L., and Mohler, S. R., 1980, The current role of alcohol as a factor in civil aircraft accidents. Report No. FAA-AM-80-4, Office of Aviation Medicine, Federal Aviation Medicine.

Safety Analysis Division, Office of Aviation Safety, Federal Aviation Administration, 1982, The influence of total flight time, recent flight and age on class III pilot accident rates. Unpublished report, 15 November.

SPENCE, J. T., UNDER WOOD, B. J., DUNCAN, C. P., and CoTtON, J. W., 1968, Elementary Statistics, second edition (New York: Appleton-CEnTURY CRAFTS).

URBAN, R. F., 1984, Comparative analysis of social, demographic, and flight-related attributes between accident and non-accident general aviation pilots. Aviation, Space and Environmental Medicine, 55, 308-312. 